\title{
イオンクラスタービーム法で作製したグラニュラー $\mathrm{Fe} / \mathrm{Ag}$ 合金膜の構造と磁気抵抗
}

\author{
Structure and Magnetoresistance of Granular Fe/Ag Alloys Produced \\ by the Ion Cluster Beam Method
}

\author{
隅山兼治・マクロウフ, サラ・日原岳彦・若生公郎・山室佐益・櫻井雅樹・神山智明・鈴木謙爾 \\ 東北大学金属材料研究所, 仙台市青葉区片平 2-1-1 (严980)
}

\begin{abstract}
K. Sumiyama, S. Makhlouf, T. Hihara, K. Wakoh, S. Yamamuro, M. Sakurai, T. Kamiyama and K. Suzuki Institute for Materials Research, Tohoku Univ., 2-1-1 Katahira, Aoba-ku, Sendai 980
\end{abstract}

The structure and magnetoresistance (MR) of granular $\mathrm{Fe} / \mathrm{Ag}$ alloy films produced by an ion-clusterbeam technique have been observed. Small-angle $\mathrm{X}$-ray scattering and transmission electron microscope measurements show chemical fluctuation in the range of $15 \mathrm{~nm}$ and small Fe clusters about $5 \mathrm{~nm}$ in diameter. At $4.2 \mathrm{~K}$, an $\mathrm{MR}$ effect is very large between 10 and 40 at $\% \mathrm{Fe}$, with the maximum $\mathrm{MR}$ value at around $20-30$ at $\% \mathrm{Fe}$. When the Fe concentration increases from the Ag-rich side, the electrical resistivity rapidly increases at around $50 \mathrm{at} \% \mathrm{Fe}$. These features are ascribable to the geometrical and magnetic percolations of the $\mathrm{Fe}$ clusters. The field dependence of the MR is composed of saturationtype and non-saturation-type contributions, even at $140 \mathrm{kOe}$, indicating the contributions of large Fe clusters, small $\mathrm{Fe}$ atoms and molecules in the Ag-rich matrix, and Fe atoms located at the interfaces between Fe clusters and Ag matrix.

Key words: iron/silver granular film, magnetoresistance, small-angle X-ray scattering, X-ray diffraction, transmission electron miroscope, extended $\mathrm{X}$-ray absorption fine structure

\section{1.はじめに}

近年，強磁性遷移金属層と非磁性金属層から成る人工 格子膜において巨大磁気抵抗効果が見いだされ，基礎・ 応用両面で話題になっている11,2\}. 強磁性首間で反強磁 性的な結合が生じる場合や，各強磁性層の磁気異方性が 異なる場合に, 消磁状態と磁化状態での伝導電子のスピ ン不規則散乱の差異が大きいことがその主因と考えられ ている. 特に, 強磁性体・非磁性体界面怔磁気抵抗の支 配因子であることが示唆されている，それを実証するよ うに, 気相・液相急冷法により, 非混合系の $\mathrm{Co}-\mathrm{Cu}, \mathrm{Fe}-$ $\mathrm{Cu}$ 合金の強制固溶体を作製した後, 焼鈍して微細な強
磁性結晶粒を析出させたグラニュラーマテリアルにおい ても, 巨大磁気抵抗が実現できることが分かり，興味あ る研究結果が多数報告されつつある3.4\%. グラニュラー マテリアルは人工格子膜のような高度の組織制御を要し ない点で注目されるが，その代わりに，焼鈍プロセスが 必要であり，低温焼鈍で，強磁性クラスターの密度，サ イズ，分布状態を制御することは容易でない゙，

我々のグループでは，イオンクラスタービーム (ICB) 法を用い, 微小金属クラスターを出発材料として,ナ， スケール構造制御材料の創製をめざしている6,7, この ICB 成膜過程に扔いては, 高温の坩堝ノズルから過飽和 蒸気が粘性流として噴出する際，断熱膨張により冷却さ れクラスターが形成されるので，グラニュラー状態の構 造・組織制御が可能となる、本報告では, ICB 法を用い $\mathrm{Fe}$ クラスターを Ag マトリックス中に埋め込んだ Fe/ $\mathrm{Ag} ク ゙ ラ ニ ュ ラ ー$ 合金膜を作製し，その磁気抵抗特性と 構造, 微細組織の相関性を検討した結果について述べ る。

\section{2. 実 験方法}

クラスターイオンビーム (ICB) 装置で試料を作製する 際, 約 $1800^{\circ} \mathrm{C}$ に加熱した二重るつほ（モリブデン外る つぼ, ジルコニア内るつぼ) のノズル（穴径 $1.4 \mathrm{~mm}$, 長 さ1.4 mm) から Feを，蓋なしの約 $1200^{\circ} \mathrm{C}$ に加熱した カーボンるつぼから Agをそれぞれ蒸発させ，ポリイミ ド膜，アルミニウム膜あるいは電子顕微鏡用マイクログ リッド上に, $\mathrm{Fe} / \mathrm{Ag}$ 合金膜を堆積させた，超伝導マグ ネット（最高磁場 $140 \mathrm{kOe}$ ) 中 $4.2 \mathrm{~K}$ で四端子法により 磁気抵抗 (MR) 測定, 超伝導マグネット（最高磁場 60 $\mathrm{kOe})$ 中 $4.5 \mathrm{~K}$ で SQUID 磁束計を用いた磁化测定を 行った. グラファイト単結晶で単色化した Cu- $K_{a}$ 線を用 いた X 線回折 (XRD)，X 線小角散乱 (SAXS) により, 短 
距離および中距離構造解析を行った．冷陰極電界放出型 の高分解能電子顕微鏡 (HRTEM; 日立製作所製 HF 2000)により微細組織，構造を観察するととむに，それ に付設したエネルギー分散型 X 線分析計 (EDX)による ナノメートル領域の化学分析を試みた. さらに, 高エネ ルギー物理学研究所放射光利用施設に招いて, Fe-K 吸 収端の広領域 X 線微細構造 (EXAFS) スペクトルを測定 した。なお，XRD，MR，EXAFS 測定用試料には厚さ 約 $500 \mathrm{~nm}$ の合金薄膜, SAXS 測定には厚さ約 $2 \mu \mathrm{m} の$ 厚膜, HRTEM 測定には厚さ約 $10 \mathrm{~nm}$ の極薄膜を, そ れぞれ同一条件下で作製した。

\section{3. 実験結果}

Fig. 1 は Fe/Ag グラニュラー合金膜の $4.2 \mathrm{~K}$ におけ る磁気抵抗比 $\Delta \rho / \rho$ の磁場变化を示す $(\Delta \rho / \rho=[\rho(H)-$ $\rho(0)] / \rho(140) ; \rho(H)$ は磁場 $H$ (単位 $\mathrm{kOe}$ ) に打ける電気抵 抗). 強磁性体之非磁性体を交互に堆積させた人工格子 膜と同様の巨大磁気抵抗が観測される、いずれの試料も $\Delta \dot{\rho} / \rho$ の絶対值は, $H<20 \mathrm{kOe}$ で急激に増加した後, $H$ $>30 \mathrm{kOe}$ ではほぼ直線的に増加し, 最大磁場 $140 \mathrm{kOe}$ においても飽和する兆候はみられない，一般に，強磁性 体の磁気抵抗変化は磁化の自乗に比例することが経験的 に知られているが, Fig. 2 に示すように, Fe/Ag グラ ニュラー合金膜の磁化曲線は $H=1 \mathrm{kOe} て ゙$ 既に飽和し, この経験則は成立しない8).

$\mathrm{Fe} / \mathrm{Ag}$ グラニュラー合金膜の特異な磁気抵抗効果の 原因を探るため, 多角的な構造解析, 組織観察を行った.

Fig. 3 に XRD の結果を示す. いずれの合金膜も fcc

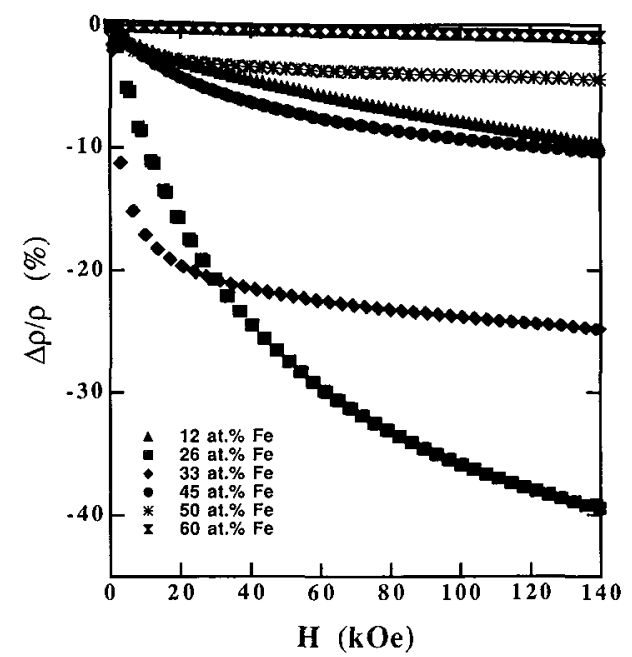

Fig. 1 Magnetoresistance ratio, $\Delta \rho / \rho$, at $4.2 \mathrm{~K}$ for $\mathrm{Fe} / \mathrm{Ag}$ granular alloy films.

日本応用磁気学会誌 Vol. 18, No. 3, 1994

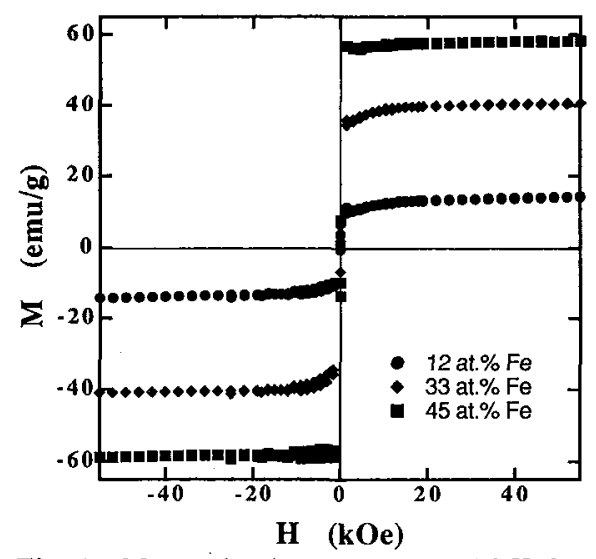

Fig. 2 Magnetization curves at $4.2 \mathrm{~K}$ for $\mathrm{Fe} / \mathrm{Ag}$ granular alloy films.

構造の回折線が支配的であり，その線幅よりシェラーの 式に基づき算出した結晶粒径は約 $20 \mathrm{~nm}$ である，ただ し，この回折図形では，Cu- $K_{\alpha}$ 線の Fe による吸収が著 しく，また後述するように Fe クラスターのサイズが極 めて小さいことに起因して，Feクラスターあるいは Fe 高濃度領域の構造を判別することは困難である.

グラニュラーマテリアルのようなナノスケールで組成 あるいは構造摇らぎを有する物質の中距離構造を調べる には, SAXS が適している. Fig. 4 は, X 線散乱強度を 散乱ベクトル $h(h=4 \pi \sin \theta / \lambda)$ の関数として両対数ス ケールで表示している，hが減少するに従い散乱強度が

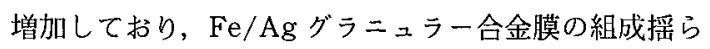
ぎが著しいことを示唆している. $h=0.2 \sim 0.5 \mathrm{~nm}^{-1}$ の ギニエ領域で見積もった摇らぎ領域の平均粒径は, 約 $15 \mathrm{~nm}$ となる. $h=0.7 \mathrm{~nm}^{-1}$ 付近にす粒子間相関に対応 する微細構造が存在するが, バックグラウンドの蛍光 X

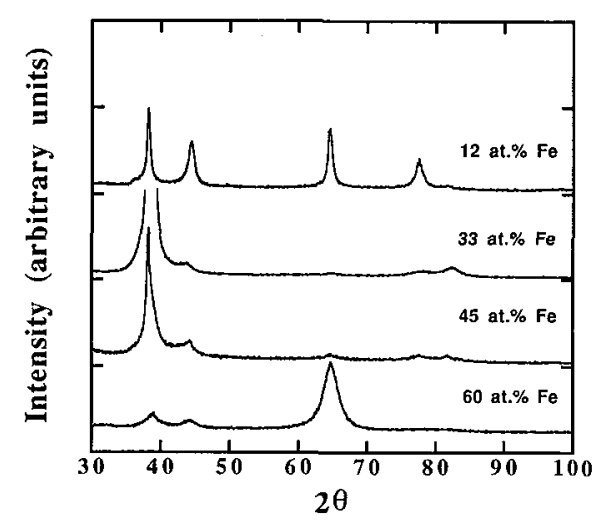

Fig. 3 X-ray diffraction patterns of $\mathrm{Fe} / \mathrm{Ag}$ granular alloy films. 


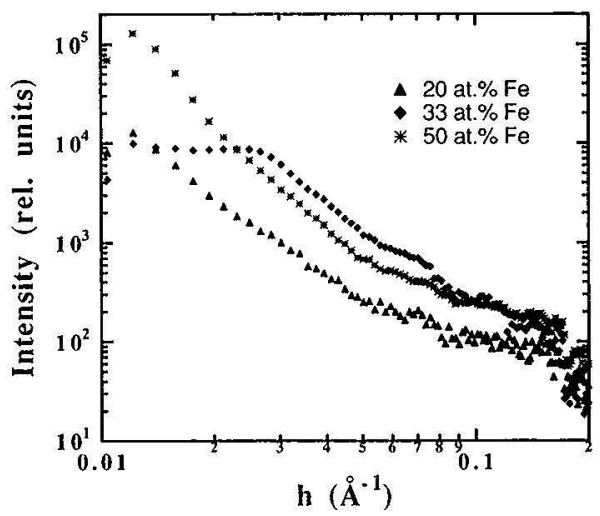

Fig. 4 Small-angle X-ray scattering intensity as a function of the scattering vector, $h$, for $\mathrm{Fe} / \mathrm{Ag}$ granular alloy films.

線強度が強く，その解析は不可能である。

$\mathrm{X}$ 線構造解析のような逆格子空間での平均構造に関 する情報を補足するには，電子顕微鏡を用いた実空間で の構造, 組織の直接観察が重要である.Fig. 5 は低倍率 の $\mathrm{Fe} / \mathrm{Ag}$ グラニュラー合金膜の組織および電子回折図 形を示す. $\mathrm{Fe} / \mathrm{Ag}$ グラニュラー合金膜は, $\mathrm{X}$ 線回折の結 果から予想されるように，ナノスケールの微細組織から 構成されており，回折リングあほぼ fcc 構造であること を示している. 一方, Fig. 6 に示すように Fe/Ag グラ ニュラー合金膜（化学組成 $15 \mathrm{at} \% \mathrm{Fe}$ ) の HRTEM 写真 においては, 外径 $20 \mathrm{~nm}$ の大きさの領域が連結した組

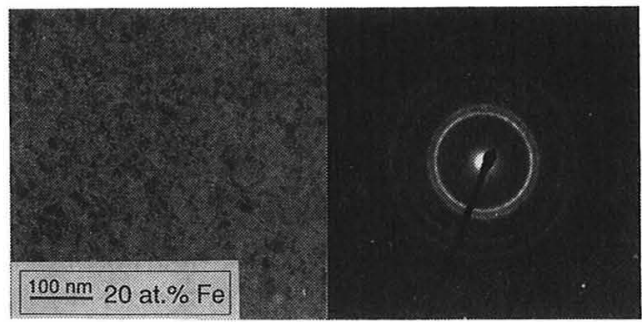

Fig. 5 Low-magnification TEM image and electron diffraction pattern of $\mathrm{Fe} / \mathrm{Ag}$ granular alloy films.

織が存在する、このサイズは, X 線回折ピークの線幅よ り見積もった平均粒径 (約 $20 \mathrm{~nm}$ ) ならびにX 線小角散 乱のギニェ領域から見積もった平均的な組成摇らぎの領 域 (約 $15 \mathrm{~nm}$ ) と良く対応している. したがって, 基板 上で核生成・成長した Agクラスター（より小さいサイ ズの Feクラスターを含む) 同土が合体するというグラ ニュラー膜の成長過程を反映していると考えられる.さ らに,この摇らぎの内部に, 写真で黒いコントラストの 付いた約 $5 \mathrm{~nm}$ の領域で整合した格子縞が点在するのが 観测される. 特に, $1 \sim 2 \mathrm{~nm}$ サイズの電子ビームを照射 して EDX 組成分析を行うと, いずれの個所です $\mathrm{Ag} \cdot K_{a}$ 線が観测されるのに対して，飛び飛びの約 $5 \mathrm{~nm}$ の領域 で強い Fe- $K_{a}$ 線が観測され, Feがクラスターを形成し ていることを示唆している. 図に示すように, 15 at\% Fe の場合Feクラスターが互いに接触する確率は低い (b)

(a)
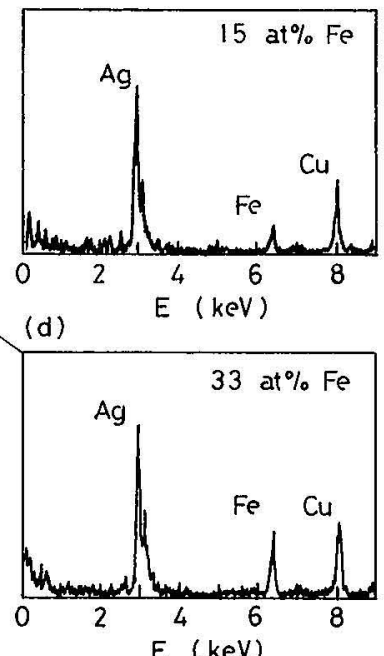

Fig. 6 (a) High-resolution TEM image of an Fe/Ag granular alloy film (15at\%Fe). (b) Nanoelectronbeam energy dispersive X-ray analysis for a wide range of the deposited film. (c) and (d) Similar analyses those for the regions indicated in Fig. 5(a). 


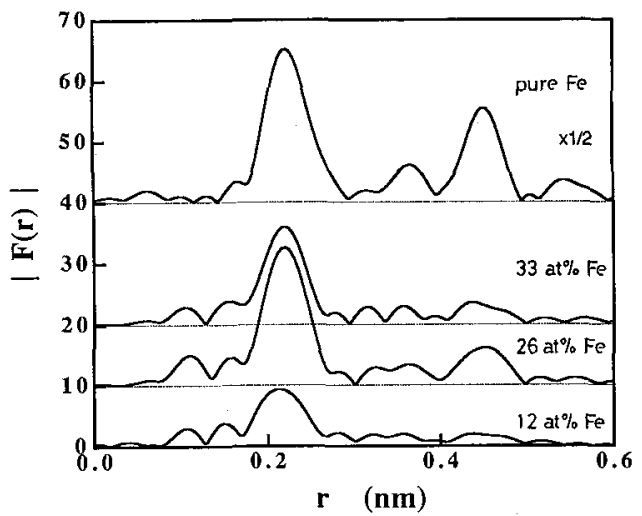

Fig. 7 Fourier transformed EXAFS function, $F(r)$, for $\mathrm{Fe} / \mathrm{Ag}$ granular alloy films.

が, 30 at\% Fe 以上になると Feクラスターの連結も顕 著になる9!

さらに，Feクラスターの局所構造を明らかにするた

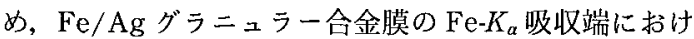
るEXAFS スペクトルを湘定した，Fig. 7 はをれをフー リェ変換して求めた. EXAFS 動径構造関数 $F(r)$ を示 す. $\mathrm{Fe}$ 原子周りの第 4 隣接付近まで, $\mathrm{Fe} / \mathrm{Ag}$ グラニュ ラ一合金膜と純 $\mathrm{Fe}$ 試料の $F(r)$ の形状が類似しており, 合金膜の堆積状態で Fe がずでに bcc 構造をとることを 示している．ただし合金膜の $F(r)$ の強度が低く, bcc 構 造は相当乱れていると推測される.

\section{4. 考 察}

Fig. 8 は $\mathrm{Fe} / \mathrm{Ag}$ グラニュラー合金膜の $4.2 \mathrm{~K}$ におり る電気抵抗 $\rho$, 磁気抵抗比 $\Delta \rho / \rho$ の組成依存性を示す， $\rho$ は $\mathrm{Ag}$ 高濃度側で小さく, $50 \mathrm{at} \% \mathrm{Fe}$ 付近で急激に増大 し，それ以上 $\mathrm{Fe}$ 濃度が増加すると漸減する，一方， $\Delta \rho /$ $\rho$ は $\mathrm{Ag}$ 高濃度側から Fe 濃度が増すにつれて増大し， $20 \sim 30$ at $\% \mathrm{Fe}$ 付近で極大值をとり，さらに， $\mathrm{Fe}$ 高濃度 側で減少する.

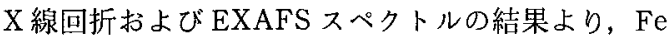
クラスター内部の原子配列は乱れていると推測され，ま た， $\mathrm{Fe}$ は $\mathrm{Ag}$ に比べ電気抵抗が大きい， Fe 濃度の増加 とともに, $\rho$ の大きい Fe クラスターが増加し, 接触, 合 体し，試料の両端で連結が完了するいわゆるパーコレー ションが生じるであろう。般的に，クラスタ一の体積 比率が臨界值 $V_{\mathrm{c}} \sim 42 \mathrm{vol} \%$ においてクラスターパーコ レーションが達成される10111)。この $V_{\mathrm{c}}$ は $\mathrm{Fe} / \mathrm{Ag}$ グラ ニュラー合金膜の組成に換算すると 51 at \% Fe となる.

磁気抵抗効果はクラスター間の磁気的結合に依存し， したがってクラスター間距離により变化する ${ }^{12)} . \mathrm{Fe} / \mathrm{Ag}$

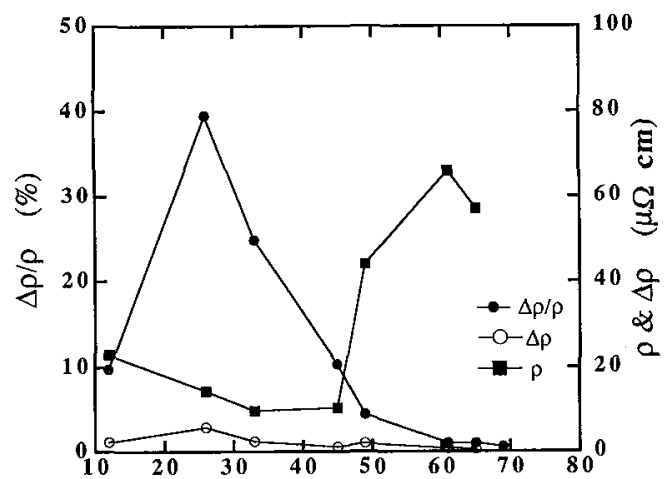

Fe content (at $\%$

Fig. 8 Concentration dependence of the electrical resistivity, $\rho$, and the absolute value of the magnetoresistance ratio at $H=140 \mathrm{kOe},|\Delta \rho / \rho|$, for $\mathrm{Fe} / \mathrm{Ag}$ granular alloy films.

人工格子の場合 ${ }^{13)}, \mathrm{Ag}$ 層を介した $\mathrm{Fe}$ 層間の $\mathrm{RKKY}$ 的 相互作用は, $\mathrm{Ag}$ 層の厚さが約 $1.6 \mathrm{~nm}$ のとき反强磁性 的で最む強くなり，磁気抵抗効果も著しくなると期待さ れる，そこで単純化したモデルとして，電子顕微鏡で観

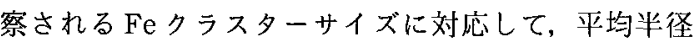
$2.5 \mathrm{~nm}$ の $\mathrm{Fe}$ クラスターを考元，その周囲を厚さ 0.8 $\mathrm{nm}$ の Ag の殼で覆った半径 $3.3 \mathrm{~nm}$ の重層クラスター を想定する．また簡単のため， Ag 款は Fe を含まないと 仮定する，この重層クラスターのパーコレーションも同 様に $V_{\mathrm{c}} \sim 42 \mathrm{vol} \%$ で達成されるとすると，それに対応 する芯部の $\mathrm{Fe}$ クラスターの体積比率は約 $19 \mathrm{vol} \%$ ，組 成に換算すると約 $25 \mathrm{at} \% \mathrm{Fe}$ となる，このように $\rho$ が急 激に変化する組成， $\Delta \rho / \rho$ が極大となる組成は，2 種類の パーコレーションと関係づけることができる．ただし， 厳密には, Fe クラスターの内部の組成の摇らぎ, サイズ 分布，界面形状む考慮する必要があろう。

さらに，ICB 法ではクラスターのサイズを制御でき ず，原子・分子状の $\mathrm{Fe}$ も存在し，そ机らがスピングラ 又的な磁性を示す可能性が高い(4)，大きな $\mathrm{Fe}$ クラス ター中の Fe 原子磁気モーメントが磁場配向した後も, 原子・分子状の Fe の磁気モーメントが容易に磁場方向 に配向せず， スピン不規則散乱が残り，磁気抵抗比が高 磁場中でも変化すると考元られる15)。 また，ICB 法で作 製した $\mathrm{Fe} / \mathrm{Ag}$ グラニュラー合金膜に扰いて，磁気抵抗 效果が焼鈍に伴い単調に減少すること ${ }^{16)}$ ：未焼鈍状態で のクラスターとマトリックスの界面が複雑に入り組み, 構造・組織の乱机が著しいことから類推して, 界面に位 置する $\mathrm{Fe}$ 原子も磁気抵抗の磁場依存性に寄与すると考 
えられる17. ただし，原子・分子状の $\mathrm{Fe}$ や界面に位置 する $\mathrm{Fe}$ 原子は容易に磁場配向しないが，その原子数は 少ない，一方大きなクラスターの内部に含まれる $\mathrm{Fe}$ 原 子数が圧倒的に多く，それらは磁場配向しやすいので, 合金膜の磁化も容易に飽和する。

\section{5.おわりに}

イオンクラスタービーム源から発生した金属クラス ターを直接非磁性 $\mathrm{Ag}$ マトリックス中に分散させたグラ ニュラー合金膜は，スパッタ法や液体急冷法で作製した 合金膜と異なり，熱処理を施さなくとも巨大磁気抵抗を 示す。この合金膜に打いては， $\mathrm{Ag}$ マトリックス中に bcc 構造を有する $\mathrm{nm}$ サイズの Feクラスターが多数存在 し，原子・分子状の小さなクラスターと共存する．合金 膜の巨大磁気抵抗効果は, 磁場中での強磁性 Fe クラス 夕一内部の $\mathrm{Fe}$ 原子の磁気モーメント, 界面の $\mathrm{Fe}$ 原子 の磁気モーメントならびにスピングラス的な $\mathrm{Fe}$ 原子・ 分子の磁気モーメントの配向によるスピン不規則散乱の 減少に起因する。約 25 at\% $\mathrm{Fe}$ で, $\mathrm{Fe}$ クラスターの磁気 的パーコレーションが達成され磁気抵抗効果が最大にな るとともに, 約 50 at\% Fe で Feクラスターの化学的 パーコレーションが達成され，より高 $\mathrm{Fe}$ 濃度側で電気 抵抗が急增する。

謝 辞 本研究は文部省科学研究費補助金・創成的基 礎研姿「ナノスケール構造制御機能材料の開発」(課題番 号 03NP0501，04NP0501 および 05NP0501）の下に 行ったあのであり，関係各位のご支援に感謝致します. また，磁化测定においてお世話になった，藤森啓安教授， 高梨弘毅博士に感謝致します。

\section{文献}

1）藤森啓安編：日本金属学会会報, 31, 777 (1992), 特集「金 属人干格子の構造, 物性とその応用」.

2) 新庄輝也：応用物理，61, 1214 (1992)

3) A. E. Berkowitz, J. R. Mitchell, M. J. Carey, A. P. Zhang, F. E. Spada, F. T. Parker, A. Hutten and G. Tomas: Phys. Rev. Lett., 68, 3745 (1992).

4) J. Q. Xiao, J. S. Jiang and C. L. Chien: Phys. Rev. Lett., 68, 3749 (1992).

5) A. Maeda, M. Kume, S. Oikawa, T. Tanuma, Y. Shimizu and M. Doi: J. Phys. Cond. Mat., 5, 1 (1993).

6) S. A. Makhlouf, K. Sumiyama, H. Onodera, K. Wakoh, K. Suzuki: Nuclear Instr. Methods Phys. Reser., B76, 197 (1993).

7) K. Sumiyama, K. Wakoh, T. Oishi, G. Hohl, T. Hihara, M. Sakurai, S. Yamamuro and K. Suzuki: Mater. Trans., JIM, 34, 646 (1993).

8) S. A. Makhlouf, K. Sumiyama, K. Wakoh, K. Suzuki, H. Takanashi and H. Fujimori: J. Magn. Magn. Mat., 126, 485 (1993).

9) S. Yamamuro, K. Sumiyama, K. Wakoh and K. Suzuki: to be published in Mater. Trans., JIM.

10) B. Abeles, P. Sheng, M. D. Coutts and Y. Arie: Adv. Phys., 24, 407 (1975).

11) B. Weitzel, A. Schreyer and H. Micklitz: Eur. Phys. Lett., 12, 123 (1990).

12) S. Zhang: Appl. Phys. Lett., 61, 1855 (1992).

13) Q. Leng, V. Cros, R. Schafer, A. Fuss, P. Grunberg and W. Zinn: J. Magn. Magn. Mat., 126, 367 (1993).

14) V. Manns, B. Scholz, W. Keune, K. P. Schletz, M. Braun and E. F. Wassermann: Trans. JIM, 29(Suppl.), 295 (1988).

15) R. Berman and J. Kopp: J. Phys. F: Metal Phys., 3, 847 (1973).

16) S. A. Makhlouf, K. Sumiyama, K. Wakoh, K. Suzuki: Jpn. J. Appl. Phys., 33, 1323 (1994).

17) Y. Asano, A. Oguri, J. Inoue and S. Maekawa: submitted to Phys. Rev. Lett.

1993 年 11 月 15 日受理, 1994 年 3 月 18 日採録 